\title{
Evaluation of patient referrals to family physicians in Georgia
}

\author{
TENGIZ VERULAVA ${ }^{1, A-F}$, DALI BERUASHVILI 2, A-C, REVAZ JORBENADZE3, A, D, E, \\ ORCID ID: 0000-0001-8110-5485 \\ EKATERINE ELIAVA 4, D, E \\ ${ }^{1}$ Health Policy and Insurance Institute, School of Business, Ilia State University, Tbilisi, Georgia \\ ${ }^{2}$ School of Business, Ilia State University, Tbilisi, Georgia \\ ${ }^{3}$ G. Chapidze Emergency Cardiology Center, Tbilisi, Georgia \\ ${ }^{4}$ Senamedi Hospital, Senaki, Georgia
}

A - Study Design, B - Data Collection, C - Statistical Analysis, D - Data Interpretation, E - Manuscript Preparation, F - Literature Search, G - Funds Collection

Summary Background. Adequate utilization of primary care directly reflects the health status of the population. In Georgia (Republic), many patients seek care without a referral by a primary-care provider, and as a result, patient referral rates to family physicians are low. A tendency of patient self-referral behavior may reduce the effectiveness of the healthcare system.

Objectives. The purpose of the research is to study the problem of the low rate of patient referrals to family physicians in Georgia. Material and methods. Within the quantitative survey, 20 family physicians and 300 patients were interviewed through a semi-structured questionnaire in different regions of Georgia.

Results. Patient referral rates to family physicians are low. $15 \%(n=3)$ of family physicians recognize that patients often address them only for a referral to specialists. Only $5 \%(n=3)$ of family physicians provide preventive consultations on occasion and $50 \%(n=10)-$ in the case of need only. $70 \%(n=14)$ of family physicians think that their remuneration is not adequate for their work and that they work more than they are paid. $35 \%(n=105)$ of respondents in the case of a health problem address both a family physician and a specialist-physician. $42 \%(n=126)$ of patients visit a family physician once a year or do not visit at all, and $47 \%(n=141)$ of patients believe that the family physician institute needs some changes.

Conclusion. The result suggests that the low rate of patient referrals to family physicians is due to distrust towards family physicians, which is related to a lack of qualification of physicians and low public awareness of the competence of the family physicians. Due to inadequate reimbursement, family physicians do not have enough motivation to provide adequate service, and the lack of continuous professional education negatively affects their professional development. It is recommended to raise public awareness about primary care, to introduce effective methods for payment of family physicians and to increase the role and affordability of continuous professional education.

Key words: primary health care, family practice, referral and consultation, Georgia (Republic).

Verulava T, Beruashvili D, Jorbenadze R, Eliava E. Evaluation of patient referrals to family physicians in Georgia. Fam Med Prim Care Rev 2019; 21(2): 180-183, doi: https://doi.org/10.5114/fmpcr.2019.84555.

\section{Background}

Health care system orientation to primary care has a positive effect on the continuity and coordination of medical services, which simultaneously reduces the cost of unnecessary specialized services and improves the health of the population. In a health care system focused on primary health care, the role of family physicians as a gatekeeper increases. In such a system, the patient tries to apply firstly to a family physician, then, if necessary, apply for specialized services to specialists.

Studies have confirmed that in a health care system where referral to special medical care is performed through a family physician, the health care costs decrease $[1,2]$, and continuous medical supervision is at a high level. Patients who are under the permanent supervision of a primary care physician are less likely to need specialized services or hospitalization [3-5]. The need for urgent medical care is less in patients who utilize regular primary health care services $[6,7]$. Thus, primary care is considered as a mechanism for preventing health care costs, which is important for a low-income country like Georgia [8, 9].

One of the most important components of assessment of the effectiveness of medical care is the patient referral rate to family physicians. It aims to analyze how often the population applies to primary health care institutions. Studies show that the primary healthcare system in Georgia has failed to develop under the standards that have been applicable in many developed countries for several years [10-12]. This is confirmed by the fact that the patient referral rate to family physicians is 3.6 (up to 7.5 in European countries), which is due to the fact that patients have less motivation to address the primary care physician for prevention. Patients prefer hospital services [13-15]. It is obvious that the low development of primary care and family physician institutes is negatively impacting the health status of the population and health care costs [16-18].

\section{Objectives}

The purpose of the work is to study the problem of the low rate of patient referrals to family physicians in Georgia. The objective of the research is to identify the factors that cause low confidence in family physicians.

\section{Material and methods}

The research is a cross-sectional study and is concerned with the problems in primary care in Georgia (Republic). Within 
the quantitative survey, 20 family physicians and 300 patients (enrolled in a family physician's list) were interviewed under a semi-structured questionnaire in different cities and regions of Georgia. The random selection method was used for selection of the survey contingent. The questionnaire for this study was developed based on a review of literature and specificities of the primary health care system in Georgia. After the questionnaire had been built, the information of respondents was collected by a convenient sampling method. The data was then processed by SPSS software.

The main limitation of the survey is the fact that it was conducted in only a few cities/regions due to lack of time.

The protocol for the research project was approved by the suitably constituted Ethics Committee of the Ilia State University, within which the work was undertaken and conforms to the provisions of the Declaration of Helsinki of 1995.

\section{Results}

\section{Family physicians' survey results}

Within the scope of the survey, 20 family physicians were interviewed. About $60 \%(n=12)$ of respondents serve 10 to 15 patients per day. $15 \%(n=3)$ of family physicians recognize that patients often address them only for a referral to specialists. The survey makes it clear that only $5 \%(n=3)$ of family physicians provide preventive consultations on occasion and $50 \%(n=10)$ in the case of need only (Table 1).

\begin{tabular}{|c|c|c|}
\hline & $n$ & $\%$ \\
\hline $\begin{array}{l}\text { The number of patients received by a family } \\
\text { physician during a day } \\
\text { Less than } 10 \\
\text { From } 10 \text { to } 15 \\
\text { More than } 15\end{array}$ & $\begin{array}{l}1 \\
12 \\
7\end{array}$ & $\begin{array}{l}5 \\
60 \\
35 \\
\end{array}$ \\
\hline $\begin{array}{l}\text { The patients often address the family physicians } \\
\text { only to receive a referral to a specialist } \\
\text { Yes } \\
\text { No } \\
\text { More or less } \\
\text { Not sure }\end{array}$ & $\begin{array}{l}3 \\
5 \\
11 \\
1 \\
\end{array}$ & $\begin{array}{l}15 \\
25 \\
55 \\
5\end{array}$ \\
\hline $\begin{array}{l}\text { Do you provide preventive consultations to your } \\
\text { patients? } \\
\text { Sometimes } \\
\text { Only in case of need } \\
\text { I have no time for such consultations }\end{array}$ & $\begin{array}{l}3 \\
10 \\
7\end{array}$ & $\begin{array}{l}5 \\
50 \\
35\end{array}$ \\
\hline $\begin{array}{l}\text { Assessment of remuneration by the interviewed } \\
\text { physicians } \\
\text { Low remuneration } \\
\text { Satisfactory remuneration } \\
\text { Good remuneration }\end{array}$ & $\begin{array}{l}13 \\
6 \\
1\end{array}$ & $\begin{array}{l}65 \\
30 \\
5\end{array}$ \\
\hline $\begin{array}{l}\text { Adequacy of remuneration as assessed by the } \\
\text { interviewed family physicians } \\
\text { Works more than paid } \\
\text { Pay is adequate to the work } \\
\text { Works somehow less than paid }\end{array}$ & $\begin{array}{l}14 \\
1 \\
5\end{array}$ & $\begin{array}{l}70 \\
5 \\
25 \\
\end{array}$ \\
\hline $\begin{array}{l}\text { Whether family physicians have nurses? } \\
\text { Yes } \\
\text { No }\end{array}$ & \begin{tabular}{|l|}
8 \\
12 \\
\end{tabular} & $\begin{array}{l}40 \\
60\end{array}$ \\
\hline $\begin{array}{l}\text { Do you have career development, professional } \\
\text { improvement opportunity? } \\
\text { Yes } \\
\text { No } \\
\text { More or less } \\
\text { Not sure }\end{array}$ & \begin{tabular}{|l|}
0 \\
7 \\
10 \\
3 \\
\end{tabular} & $\begin{array}{l}0 \\
35 \\
50 \\
15 \\
\end{array}$ \\
\hline
\end{tabular}

\begin{tabular}{|l|l|l|}
\hline $\begin{array}{l}\text { Do you attend educational programs for family } \\
\text { physicians? }\end{array}$ & & \\
Yes & 3 & 15 \\
No & 7 & 35 \\
More or less & 6 & 30 \\
Not sure & 4 & 25 \\
\hline Do you follow medical news through medical & & \\
journals and articles? & & \\
Yes & 10 & 50 \\
No & 0 & 0 \\
More or less & 9 & 45 \\
Not sure & 1 & 5 \\
\hline Do you get updated guidelines via the Internet? & & \\
Yes & 7 & 35 \\
No & 6 & 30 \\
More or less & 7 & 35 \\
Not sure & 0 & 0 \\
\hline
\end{tabular}

Physicians have named low pay the reason for low motivation. One of the ways to solve existing primary care problems is an increase in salaries. The majority $(65 \%, n=13)$ think that their remuneration is low. In addition, $70 \%(n=14)$ of family physicians think that their remuneration is not adequate to their work and that they work more than they are paid.

The survey found that $60 \%(n=12)$ of family physicians do not have nurses. Considering that nurses play a significant role in providing services, their absence in the family medicine team negatively affects the quality of service, and therefore the patient's satisfaction. $50 \%(n=10)$ of family physicians think that they are more or less able to improve professionally, but $35 \%$ $(n=7)$ do not have the opportunity to do so. $35 \%(n=7)$ of respondents cannot participate in educational programs for family physicians. $50 \%(n=10)$ of family physicians are familiar with medicine news through medical journals and articles, and $45 \%$ $(n=9)$ are more or less familiar. It is noteworthy that respondents over 51 years of age do not follow the news on the Internet.

\section{Patient survey results}

$56 \%(n=168)$ of the interviewed patients were female and $44 \%(n=132)$ male. The majority have higher education $(73 \%$, $n=219)$. The health status of $48 \%(n=144)$ of respondents is average. $35 \%(n=105)$ of respondents in case of a health problem address both a family physician and a specialist-physician. At the same time, $30 \%(n=90)$ of respondents will directly address the physician. $42 \%(n=126)$ of respondents visit the family physician once a year or do not visit at all. When asked if they trust the family physician, most of the respondents $(36 \%, n=108)$ were not sure what to answer. The majority of respondents $47 \%$ $(n=141)$ believe that the family physician institute needs some changes (Table 2).

\begin{tabular}{|c|c|c|}
\hline & $n$ & $\%$ \\
\hline $\begin{array}{l}\text { Gender } \\
\text { Female } \\
\text { Male }\end{array}$ & $\begin{array}{l}168 \\
132\end{array}$ & $\begin{array}{l}56 \\
44\end{array}$ \\
\hline $\begin{array}{l}\text { Education } \\
\text { Secondary education } \\
\text { Higher education }\end{array}$ & $\begin{array}{l}81 \\
219\end{array}$ & $\begin{array}{l}27 \\
73\end{array}$ \\
\hline $\begin{array}{l}\text { Health status } \\
\text { Good } \\
\text { Average } \\
\text { Not satisfactory }\end{array}$ & $\begin{array}{l}120 \\
144 \\
36\end{array}$ & $\begin{array}{l}40 \\
48 \\
12\end{array}$ \\
\hline $\begin{array}{l}\text { Who will you mainly address in case of health } \\
\text { problems? } \\
\text { Family physician } \\
\text { Specialist-physician } \\
\text { Sometimes a family physician, sometimes } \\
\text { a specialist-physician } \\
\text { Self-medicate }\end{array}$ & $\begin{array}{l}60 \\
90 \\
105 \\
45\end{array}$ & $\begin{array}{l}20 \\
30 \\
35 \\
15\end{array}$ \\
\hline
\end{tabular}




\begin{tabular}{|c|c|c|}
\hline & $n$ & $\%$ \\
\hline \multicolumn{3}{|c|}{$\begin{array}{l}\text { How often do you address to a family physician } \\
\text { during a year? }\end{array}$} \\
\hline Once or not at all & 126 & 42 \\
\hline $2-5$ & 72 & 24 \\
\hline $6-8$ & 42 & 14 \\
\hline $9-10$ & 54 & 18 \\
\hline 11 and more & 6 & 2 \\
\hline \multicolumn{3}{|c|}{$\begin{array}{l}\text { Do you have confidence in your family physician's } \\
\text { qualification? }\end{array}$} \\
\hline Yes & 101 & 34 \\
\hline No & 91 & 30 \\
\hline Not sure & 108 & 36 \\
\hline \multicolumn{3}{|c|}{ How would you rate the family physician institute? } \\
\hline Positively & 90 & 30 \\
\hline Requires some changes & 141 & 47 \\
\hline Negatively & 54 & 18 \\
\hline Not sure & 15 & 5 \\
\hline
\end{tabular}

\section{Discussion}

The survey has shown that the rate of visiting a family physician in Georgia is lower compared to other countries. A significant part of the patients visit a family physician once a year or do not visit at all. In the case of health impairment, patients try to directly visit the specialist-physician, bypassing the family physician. The patient more often applies to specialized medical services (hospital, physician specialists) by him/herself. The existing system does not contribute to the reduction of self-referral to specialized medical services.

It is noteworthy that a greater share of respondents rarely addresses the family physician for consultation with the purpose of prevention. Family physicians are less likely to take preventive measures. This reduces the efficiency of medical care, since early detection of illness cannot be provided by preventive measures. The low rate of patient referrals to family physicians in Georgia may be due to a lack of confidence in the quality of medical care. According to family physicians, the mistrust and low satisfaction of patients are not only due to them, but also due to the fact that patients do not like the infrastructure of outpatient medical facilities, as well as standing in a queue to visit the family physician. Another important factor is also the established stereotype that family physicians are less professional than specialist-physicians. At the same time, according to family physicians, their load exceeds their pay. It should be taken into consideration that the majority of family physicians do not have a nurse and take on the work themselves.

The situation is aggravated by the fact that employers are less likely to support professional growth of family physicians. Consequently, family physicians do not have the opportunity to improve and develop skills, which is very important for people employed in medicine, as well as in any other field. The study shows that the administration of medical facilities is less interested in the problems of family physicians. Consequently, the problems are not identified, each particular issue is not re- viewed and analyzed, and the paths toward a solution are not searched for.

A separate problem is the fact that continuous professional education in the country is not mandatory. In addition, for some physicians, the academic and educational programs are not affordable, as participation in them is paid.

The study shows that a family physician's pay is low, which hinders the development of the family physician institute in the country. The physician's financing method is one of the key leverages to effectively implement health care services. It is advisable to introduce combined methods of pay for primary health care, i.e. funding other than the remuneration method (targeted remuneration and so on). Special attention should be paid to the methods of incentive remuneration of physicians to carry out prophylactic measures for beneficiaries.

The patient referral rate to family physicians in Georgia is low. Patients are trying to address specialist-physicians directly, bypassing the family physician. Most rarely address a family physician for prevention. Family physicians are less likely to take preventive measures. The low role of a family physician reduces the effectiveness of medical care, as it is not possible to detect illness early by preventive measures. Patient self-referral has a negative effect on the health of the population, reduces the quality of medical care and increases health care costs.

The low rate of patient referrals to family physicians may be due to a lack of confidence in the quality of medical care. This is mainly caused by the low qualifications of family physicians. The state and employers are less likely to support the professional growth of family physicians. Accordingly, family physicians do not have the opportunity to develop and grow professionally. It is noteworthy that continuous professional education is the country is not mandatory.

Primary health care reform will not be implemented without a properly educated family physician/nurse. In the furtherance of this goal, the level of professional training should be raised. In this aspect, there are family medicine training centers in the country where family physicians/nurses are trained. However, most of them are paid trainings and often are not affordable. With the support of donor organizations, the state should ensure development of the necessary capacities of primary health care human resources of appropriate qualifications throughout the country. The state should also support the continuous medical education of family physicians.

\section{Conclusions}

The result suggests that the low rate of patient referrals to family physicians is due to distrust towards family physicians, which is related to the lack of qualification of physicians and low public awareness of the competence of the family physicians. Due to inadequate reimbursement, family physicians do not have enough motivation to provide adequate service, and the lack of continuous professional education negatively affects their professional development. It is recommended to raise public awareness about primary care, to introduce effective methods for payment of family physicians and to increase the role and affordability of continuous professional education.

Source of funding: This work was supported by the Shota Rustaveli National Science Foundation of Georgia (grant number FR17_101). Conflicts of interest: The authors declare no conflicts of interest.

\section{References}

1. Kurpas D, Kern JB, Jacquet JP, et al. Programs of health promotion and disease prevention - examples from Europe and the US. Fam Med Prim Care Rev 2015; 17(2): 152-156.

2. Lionis C. Financial crisis and primary health care in Greece. Is it time for family medicine? Fam Med Prim Care Rev 2015; 17(3): 229-231.

3. Põlluste K, Lember M. Primary health care in Estonia. Fam Med Prim Care Rev 2016; 18(1): 74-77. 
4. Paplicki M, Susło R, Dopierała K, et al. Systemic aspects of securing the health safety of the elderly. Fam Med Prim Care Rev 2018; 20(3): 267-270, doi: 10.5114/fmpcr.2018.78272.

5. Verulava T, Maglakelidze T. Health financing policy in the South Caucasus: Georgia, Armenia, Azerbaijan. Bull Georg Natl Acad Sci 2017; 11(2): 143-150.

6. Asatiani M, Verulava T. Georgian Welfare State: Preliminary study based on Esping-Andersen's typology. Economics and Sociology 2017; 10(4): 21-28.

7. Verulava T, Sibashvili N. Accessebility to psychiatric services in Georgia. Afr J Psychiatr (S Afr) 2015; 18(3): 1-5.

8. Verulava T, Gabuldani M. Accessibility of urgent neurosurgery diseases by the state universal healthcare program in Georgia (country). GMJ 2015; 26(2): 42-45

9. Verulava T, Jorbenadze R, Dagadze B, et al. Access to ambulatory medicines for the elderly in Georgia. Home Health Care Manag Pract 2019; 31(1): 1-6.

10. Verulava T, Maglakelidze T, Jorbenadze R. Hospitalization timeliness of patients with myocardial infarction. East J Med 2017; 22(3): 103-109.

11. Verulava T, Jincharadze N, Jorbenadze R. Role of primary health care in re-hospitalization of patients with heart failure. Georgian Med News 2017; 264(3): 135-139.

12. Verulava T, Dangadze B. Health capital and economic growth: evidence from Georgia. Open Public Health J 2018; 11: 401-406.

13. Chikovani I, Sulaberidze L. Primary health care systems, case study from Georgia. Geneva: World Health Organization; 2017.

14. Ministry of Labor, Health and social affairs of Georgia. Health System Performance Assessment Report. Tbilisi: Ministry of Labor, Health and Social Affairs of Georgia; 2013.

15. Verulava T, Jorbenadze R, Barkalaia T. Introduction of universal health program in Georgia: problems and perspectives. Georgian Med News 2017; 262(1): 116-120.

16. Pollack CE, Rastegar A, Keating NL, et al. Is self-referral associated with higher quality care? Health Serv Res 2015; 50: $1472-1490$.

17. Verulava T, Jorbenadze R, Karimi L, at al. Evaluation of patient satisfaction with cardiology services. Open Public Health J 2018; 11: 201-208.

18. Tkachenko VI. Review of Ukrainian health care reformation on principles of family medicine. Fam Med Prim Care Rev 2017; 19(4): 425-429, doi: 10.5114/fmpcr.2017.70820.

Tables: 2

Figures: 0

References: 18

Received: 13.08.2018

Reviewed: 27.08 .2018

Accepted: 15.12.2018

Address for correspondence:

Prof. Tengiz Verulava

Health Policy and Insurance Institute

School of Business

Ilia State University

Kakutsa Cholokashvili Ave 3/5

Tbilisi 0162

Georgia

Tel.: (+995 32) 2220009

E-mail: tengiz.verulava@iliauni.edu.ge 